Nadje Al-Ali

Professor of Gender Studies

SOAS, University of London

na@soas.ac.uk

Tel. 0044-207-898-4547

\title{
Feminist dilemmas in (counter) revolutionary Egypt
}

Nadje Al-Ali is Professor of Gender Studies at the Centre for Gender Studies, SOAS, University of London. Her main research interests revolve around gender theory; feminist activism; women and gender in the Middle East; transnational migration and diaspora mobilization; war, conflict and reconstruction; art \& cultural studies and food. Her publications include Secularism, Gender and the State in the Middle East: The Egyptian Women's Movement (Cambridge University Press 2000); What kind of Liberation? Women and the Occupation of Iraq (2009, University of California Press, co-authored with Nicola Pratt); and Women and War in the Middle East: Transnational Perspectives (Zed Books, 2009, co-edited with Nicola Pratt). 
That gender would be central to both revolutionary and counter-revolutionary processes and developments in Egypt, as elsewhere in the region, did not come as a surprise to me, nor to any feminist scholar or activist with historical knowledge of the region and other comparable contexts. After an initial phase of anti-Mubarak and nationalist sentiments subsuming and glossing over specific gendered concerns and interests - "We are here as Egyptian citizens not as women" - feminist interventions and voices became louder and more central. From 8 March 2011 (International Women's Day) onwards, it became obvious that body politics and feminist resistance would constitute an important aspect of political contestations in post-Mubarak Egypt.

Women of all social and political backgrounds became increasingly politicized and mobilized around specific forms of gender-based violence. This in a context where the remnants of the Mubarak regime, as well as SCAF (the Supreme Council of Armed Forces), clearly tried to use women's bodies, gender norms and prevailing ideas about gender relations as a way to control, govern and intimidate protesters. The most prominent case was that of forced virginity testing by a military doctor, and the subsequent response of Samira Ibrahim, one of the victims, who, instead of staying silent in shame, resisted by going to court. Another high-profile case was the so-called "woman in a blue bra" who was beaten and kicked while lying helpless on the street with her blue bra visible. The incident was immediately followed by a large-scale protest and solidarity demonstration by women in Cairo, united across class, generations and political and religious persuasion. Increasingly, from the end of 2012 onwards, the sexual harassment of female protesters as well as wider instances of harassment have taken centre stage, both amongst feminist activists and within the media coverage of events.

Throughout this period, those of us commenting on developments in Egypt from a feminist perspective have argued that contestations about gender norms and relations are not a side-show to revolutionary and counter-revolutionary processes and developments, but are at the very heart of it. Deniz Kandiyoti (2013), for example, provocatively called the fierce backlash by the military and the remnants of old regimes "masculinist restoration": at a time when patriarchy as usual no longer functions, the desperate attempts to maintain the old rule often take on very nasty and violent forms.

Without doubt, the rapidly changing constellations and dynamics around gender and feminist positions in the context of wider political developments over the last few months have been mind-boggling. While my own observations and analysis were until recently firmly grounded in my transnational feminist ethics and politics, as well as my knowledge about comparative conditions historically (Al-Ali, 2012, forthcoming), I have to admit that I am currently at a loss as to what, in the current Egyptian context, an adequate transnational feminist strategy and position looks like.

After the violent crackdown on the Muslim Brotherhood, the removal of Morsi, and the ascendancy and popularity of General El-Sisi and the Egyptian military more broadly, I find myself struggling to understand the confidence that has 
been shown in the actions of the military, and the limited condemnation of its violent tactics amongst many Egyptian activists and intellectuals. I have no problem relating to their disdain and even hatred for the Muslim Brotherhood, whose politics and actions were anything but democratic and inclusive. Nor did they try to solve any of Egypt's most pressing economic and social problems. Yet, I have to admit that I am astonished at some of the political, intellectual and ethical acrobatics that have emerged over the past months to justify support of the military. Obviously there exists a range of views in Egypt. But I was quite shocked by the initial reactions of some of my feminist friends and colleagues in Egypt, whose hatred of the Muslim Brotherhood seemed to have translated into an initially uncritical applauding of its violent suppression, as well as a glorification of the actions of the military as "the will of the people".

Let me add here that I do feel uncomfortable about sitting in London and making recommendations to, or even worse passing judgement about, my feminist colleagues and friends in Egypt. I continue to feel humbled and profoundly impressed by their resourcefulness, commitment and resolve. I am also deeply aware that things look different from the inside, and that it is always easier to have "principled" and righteous positions sitting in a safe haven in London or New York, or in Copenhagen, Stockholm or Oslo for that matter.

That things are often more complex than they might appear from the outside, I learnt in the context of my research and activism in relation to Iraq. I have lost several friends over the last few years whose anti-imperialist and antioccupation positions translated into fierce criticism of feminist activists (or any other activist and intellectual for that matter) who participated in any political processes or transition instigated by either the occupation forces or a government lacking widespread legitimacy. For some of my friends in London, and elsewhere in the diaspora, those Iraqis who worked with the Iraqi government or engaged in any form of exchange with the occupation were traitors and were not to be trusted. My position was different and so I also became a traitor in the eyes of some, although I have always upheld my antioccupation position. I just did not think that it was either fair or realistic to expect people inside the country, living under occupation and an undemocratic government, not to try to influence processes and developments. Non-violent forms of resistance in the Iraqi context have in practice also involved engagement in the political process. And what other options, short of taking up arms and joining the armed resistance, do ordinary people have when trying to influence political developments?

At the same time, I tend to disagree with Judith Butler's position, which emerged when she was invited in late September 2013 to talk at Boğaziçi University in Istanbul to a group of students about the freedom of assembly. Butler refused to comment directly on the Gezi protests, proclaiming her lack of legitimacy as a foreign commentator on local events (Moth, 2013). While I appreciate Butler's humility and sensitivity in avoiding the frequently patronizing commentaries of western-based academics and so-called experts, I am personally troubled by the idea that you need to be there and from there to speak with credibility and authority. It reminds me too much of the essentialist identity politics of the early 
90s: you need to be black to comment on racism. Butler's position risks negating the possibility of a transnational feminist solidarity, as well as the possibility that someone who has looked at a range of historical and current contexts of protest and resistance might be able to contribute to the understanding of specific local struggles. Also, the flip side of a refusal to comment directly on events is a reifying of positions of authenticity, which inevitably involves the exclusion of dissenting voices from within.

This growing trend in Egypt has translated into a vilification of western media and western academics, who in reality represent a range of political views and express radically different analyses. Yet, in the eyes of many Egyptians, including many feminists, there exists a concerted effort on the part of western powers to discredit "the will of the Egyptian people", and the efforts of the military to crack down on the widely hated Muslim Brotherhood. The West does not understand, the argument goes, and blindly supports the Brotherhood by calling what was another instance of revolution, a coup.

Certainly, western media and commentators often get things wrong, and the situation in Egypt, as in the Middle East more broadly, is very complex and requires a historical understanding as well as a grasp of current social, political and economic conditions. However, when looking at the analyses and comments in the English-language press, as well as in on-line fora, it becomes evident that there is a wide range of views and political positions available under the heading "western". At the same time, I am increasingly suspicious and unconvinced by proclamations of "the will of the people", given that Egyptians have very different views and ideas about recent events and the future of Egypt. Whose voices and views count as those of "the people"? Do supporters of the Muslim Brotherhood lie outside this category? Or those who want things to go back to "normal" and who are already nostalgic for the Mubarak regime? And what about those groups and activists who have opposed both the Muslim Brotherhood and the military's coup and brutal crackdown, the so-called "Third Space"?

From a feminist perspective, we are already aware that the idea of "the people" often glosses over the fact that there might be different gendered interests at stake. A transnational feminist perspective looks more carefully at how gender intersects with other hierarchies of power and systems of inequality. In the current political context, I would argue that the struggle against gender-based inequalities in legislation, the widespread sexual harassment of women, the exclusion of women from decision-making processes etc., intersect with the prevailing political culture and practices of authoritarianism as well as neoliberal economic policies and practices that contribute to a profound economic crisis, high unemployment rates, and widespread poverty while also lining the pockets of a small group of economic elite.

But how do we translate this theoretical recognition into our political solidarities and practices? Here I have to acknowledge my current state of ambivalence and doubt. Do we express our support and push in transnational fora for greater representation of women and, particularly, feminist voices, in the current 
decision-making processes? Or do we stress the authoritarian and undemocratic nature of the political transition as led by the Egyptian military in the aftermath of the ousting of Morsi and the crackdown on the Muslim Brotherhood? I was rather torn in my reaction when I heard that a feminist academic and activist I greatly respect and admire was one of only five women appointed to the 50member-strong constituent assembly in September 2013. The assembly is charged with amending the existing constitution, which was drafted during the presidency of Morsi. The constitution was heavily criticized by secularists and liberals for the weight given to Islam and its strong Islamist undertones. Not surprisingly, I was therefore pleased that my inspiring colleague, whose insights and expertise go far beyond a simple "add women and stir" approach, was going to be involved in reviewing the existing constitution and suggesting amendments. At the same time, however, I felt extremely worried and uncomfortable. How can we condone a political process and that is based on a military coup with the collusion of a large section of the Egyptian population, who, by and large, did not condemn the disproportionate use of force and violence that were used to end the protests by supporters of the Muslim Brotherhood? I do not for a second believe that General El-Sisi, and the Egyptian military more widely, are interested in either women's or human rights, or the democratic values and ideas of freedom, dignity and respect associated with the revolutionary movement.

Historically, feminists in the region have on many occasions aligned themselves with authoritarian and undemocratic regimes (Egypt under Mubarak, Tunisia under Ben Ali and Iraq under Saddam Hussein being amongst the many examples). They worked with regimes which, either as part of their modernizing projects or as ways to clamp down on Islamist opposition, promoted aspects of greater gender equality and women's rights. This led to achievements in women's education, labour-force participation and legal rights. However, we also know that it contributed to an increase in social conservatism and a backlash against women's rights in the context of the revolutionary protests and developments that ousted many of the secular authoritarian regimes in the region. Currently, I worry about women's rights and broader issues of personal freedom and human rights in a situation where only two Islamists were invited to participate in amending the constitution. While a large percentage of Egyptians supported the action of the military to oust Morsi, Islamists are still an important aspect of Egypt's political landscape. Moreover, the military itself, which is clearly pulling the strings for the time being, has already repeatedly illustrated the way in which it tramples over human and women's rights and notions of democracy.

I will disappoint anyone who expects me at this point to come up with a clear sense of what is right and what is wrong. I, for myself, have decided to embrace ambivalence, doubt and a commitment to not be righteous without denying my ability and competence to analyze, interpret and comment on unfolding events. I recognize that being "inside" is different and might require strategizing, and even a sense of pragmatism, in order to contain or influence existing political processes and developments. At the same time, I maintain that "the inside" is not only diverse and multi-layered, but also contested and complex. There are, for 
example, many Egyptians, feminists, activists and intellectuals more broadly who refuse to be drawn into supporting the military just because they hate the Muslim Brotherhood. I know that my colleague belongs to that group as well, but I suspect she also feels the need to take responsibility and be constructively involved, rather than merely stand by and criticize. I can see her point and respect it. Yet, I think that there has to be an intellectual and political space for those voices - regardless of whether they are based inside or outside Egypt that comment, analyze, and possibly even make suggestions outside of polarized and dichotomous political solutions. I would argue that, at this juncture, historical depth and knowledge about comparative empirical contexts are important assets and angles that should not be so easily dismissed as either out of touch or western. Simultaneously, those of us sitting comfortably and safely at our desks elsewhere around the globe could do with a dosage of humility and doubt.

\section{References}

Al-Ali, Nadje (forthcoming), Reflections on (counter) revolutionary processes in Egypt, Feminist Review; Special Issue: Revolutions, 106, March 2014.

Al-Ali, Nadje (2012) Gendering the Arab Spring, Middle East Journal of Culture and Communication, 5(1): 26-31.

Kandiyoti, Deniz (2013) Fear and fury: women and post-revolutionary violence, Open Democracy, 14 January 2013,

http://www.opendemocracy.net/5050/deniz-kandiyoti/fear-and-fury-womenand-post-revolutionary-violence

Moth, Laura (2013) 'What Butler Didn't Say in Istanbul', Sunday's Zaman (Blog); http://www.todayszaman.com/blogNewsDetail_getNewsById.action?newsId=32 $\underline{6494}$ 